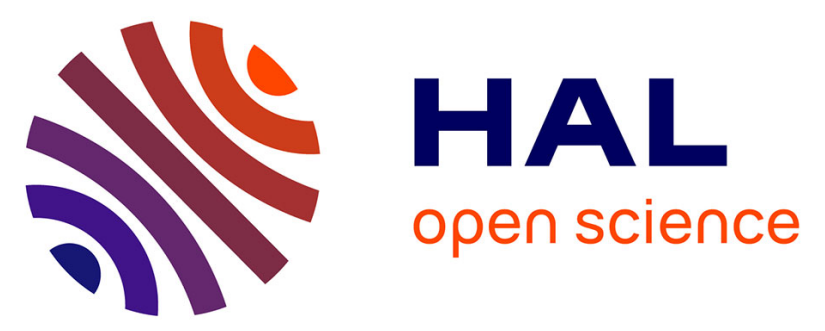

\title{
Sorption and redox speciation of plutonium at the illite surface under highly saline conditions
}

\author{
Remi Marsac, Nidhu Lal Banika, Johannes Luetzenkirchen, Alexandre \\ Diascorn, Kerstin Bender, Christian Michael Marquardt, Horst Geckeis
}

\section{- To cite this version:}

Remi Marsac, Nidhu Lal Banika, Johannes Luetzenkirchen, Alexandre Diascorn, Kerstin Bender, et al.. Sorption and redox speciation of plutonium at the illite surface under highly saline conditions. Journal of Colloid and Interface Science, 2017, 485, pp.59-64. 10.1016/j.jcis.2016.09.013 . hal-01438105

\section{HAL Id: hal-01438105 \\ https://hal-univ-rennes1.archives-ouvertes.fr/hal-01438105}

Submitted on 11 Sep 2017

HAL is a multi-disciplinary open access archive for the deposit and dissemination of scientific research documents, whether they are published or not. The documents may come from teaching and research institutions in France or abroad, or from public or private research centers.
L'archive ouverte pluridisciplinaire HAL, est destinée au dépôt et à la diffusion de documents scientifiques de niveau recherche, publiés ou non, émanant des établissements d'enseignement et de recherche français ou étrangers, des laboratoires publics ou privés. 


\section{Sorption and redox speciation of plutonium at the illite surface under highly saline}

\section{conditions}

Rémi Marsac $^{\mathrm{a}, \mathrm{b}}$, Nidhu lal Banik ${ }^{\mathrm{a}, \mathrm{c}}$, Johannes Lützenkirchen ${ }^{\mathrm{a}}{ }^{*}$, Alexandre Diascorn ${ }^{\mathrm{a}, \mathrm{d}}$, Kerstin Bender $^{\mathrm{a}}$, Christian Michael Marquardt ${ }^{\mathrm{a}}$, Horst Geckeis ${ }^{\mathrm{a}}$

Address:

${ }^{a}$ Institut für Nukleare Entsorgung, Karlsruhe Institute of Technology, P.O. Box 3640, D-76021 Karlsruhe, Germany, Tel +4972160822420; Fax: +4972160823927

Present addresses:

${ }^{\mathrm{b}}$ Ecole Nationale Supérieure de Chimie de Rennes, UMR CNRS 6226, 11 Allée de Beaulieu, F35708 Rennes Cedex 7, France.

c Institute for Transuranium Elements, European Commission P.O.Box 2340, D-76125 Karlsruhe

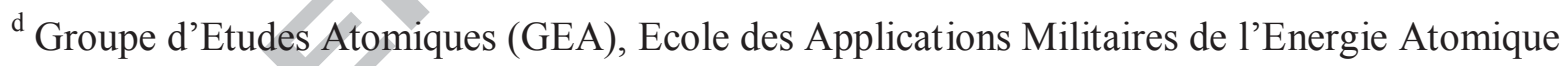
(EAMEA). BCRM Cherbourg, CC19 50115 Cherbourg-Octeville Cedex, France

*Corresponding author:

E-mail address: johannes.luetzenkirchen@kit.edu

Phone + $49721608-24023 /$ Fax $+49721608-23927$ 
Abstract. Natural groundwater may contain high salt concentrations, such as those occurring at several potential deep geological nuclear waste repository sites. Actinide sorption to clays (e.g. illite) under saline conditions has, however, been rarely studied. Furthermore, both illite surface and ionic strength may affect redox speciation of actinides like plutonium. In the present study, $\mathrm{Pu}$ sorption to illite is investigated under anaerobic conditions for $3<\mathrm{pH}_{\mathrm{m}}\left(=-\log m_{H^{+}}\right)<10$ and $m_{N a C l}=1.0$ and 3.2 molal $(\mathrm{m})$. Results are compared with previous data for $m_{N a C l}=0.1 \mathrm{~m}$. According to redox potential measurements and based on Eu(III)-illite sorption data (taken as analogue of $\mathrm{Pu}(\mathrm{III}))$, the strong effect of $m_{\mathrm{NaCl}}$ on overall $\mathrm{Pu}$ uptake observed for $\mathrm{pH}_{\mathrm{m}}<6$ is mainly attributed to the presence of $\mathrm{Pu}(\mathrm{III})$ and its competition with $\mathrm{Na}^{+}$for ion exchange sites. For $\mathrm{pH}_{\mathrm{m}}>6$, overall $\mathrm{Pu}$ uptake is largely insensitive to $m_{\mathrm{NaCl}}$ due to the prevalence of strongly adsorbed $\mathrm{Pu}(\mathrm{IV})$. By applying appropriate corrections to the activity coefficients of dissolved ions and using the 2-site protolysis non-electrostatic surface complexation and cation exchange (2 SPNE SC/CE) model, experimental data on Pu sorption to illite as a function of $\mathrm{pH}$, Eh and $m_{\mathrm{NaCl}}$ can be very well reproduced.

Keywords: Plutonium, illite, clay, saline, speciation, redox, sorption, surface complexation model, ion exchange.

\section{Graphical Abstract}

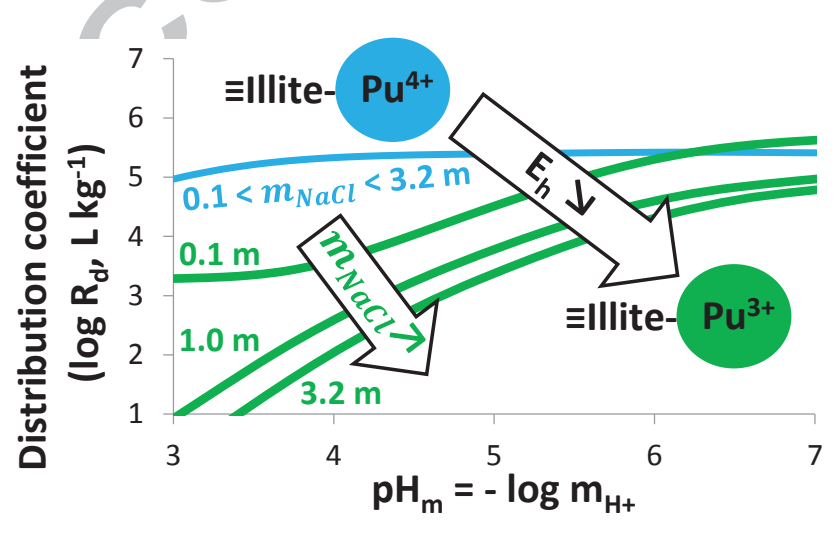




\section{Introduction}

Only few investigations of actinide uptake on clay minerals have been carried out at elevated ionic strength [1-3]. The majority of investigations pertain to $\mathrm{I}=0.1$ molar $(\mathrm{m})$ and rarely up to $1.0 \mathrm{~m}$ (e.g. [4-6]; and references therein). However, clay rock pore waters as e.g. in the Jurassic and lower Cretaceaous clay rock in Northern Germany, discussed as potentially appropriate host rock formations for a final nuclear waste repository, may contain salt contents as high as about 5 M [7]. Sedimentary rocks currently investigated in Canada are in contact with brine solutions up to $6.5 \mathrm{M}$ [8]. Therefore, detailed sorption investigations of radionuclide onto clay materials under saline conditions become necessary. At high salt concentrations, activity coefficients of aqueous species change dramatically and actinide cations may form aqueous complexes with background anions, which can affect actinides speciation (including redox equilibria), but this can be predicted. By contrast, the effect of high ionic strength on mineral (i.e. including clay minerals) surface properties is elusive. Previous studies performed at high ionic strength show that nonelectrostatic sorption models are quite suitable to simulate proton and metal ion sorption to naturally occurring surfaces, e.g. marine microalgae or bacteria [9-11]. Recently, Eu(III) sorption to illite and smectite was investigated in $0.1<m_{\mathrm{NaCl}}<3.9 \mathrm{~m} \mathrm{[3].} \mathrm{The} \mathrm{experimental} \mathrm{results} \mathrm{could}$ be described by the 2 site protolysis non-electrostatic surface complexation and cation exchange (2 SPNE SC/CE) model [5,6] coupled to the specific ion interaction theory (SIT [12]) or the Pitzer formalism [13], to account for activity coefficients of solutes in concentrated media.

Compared to $\mathrm{Eu}(\mathrm{III})$, the complex redox chemistry of $\mathrm{Pu}$ adds another dimension to sorption studies. Pu occurs in the oxidation states $+\mathrm{III},+\mathrm{IV},+\mathrm{V}$ or $+\mathrm{VI}$ and its geochemical behavior, such as solubility and mobility, strongly depends on its redox state [14-15]. Under reducing conditions, $\mathrm{Pu}(\mathrm{IV})$ and $\mathrm{Pu}(\mathrm{III})$ prevail [16-20]. However, $\mathrm{Pu}(\mathrm{III})$ sorption to minerals has rarely 
been studied separately as it is usually accompanied by $\mathrm{Pu}(\mathrm{IV})$. It has been shown, that the overall uptake of redox sensitive actinides and their redox speciation at mineral surfaces can be estimated by taking into account the uptake of the individual redox states and the measured redox potentials, i.e. the (apparent) electron activity, pe [21-22]. Using the 2 SPNE SC/CE model, previous work demonstrated the applicability of the approach to describe $\mathrm{Pu}$ uptake on illite under anaerobic conditions in $0.1 \mathrm{~m} \mathrm{NaCl}$, where the $\mathrm{Pu}(\mathrm{IV}) / \mathrm{Pu}(\mathrm{III})$ redox couple was involved [23]. Here, the approach is extended to Pu sorption and redox speciation in contact with illite under saline conditions (up to $3.2 \mathrm{~m} \mathrm{NaCl}$ ). While there is no study dedicated to tetravalent actinide sorption to illite at such high ionic strength, $\mathrm{Eu}(\mathrm{III})$ sorption to illite (often studied as chemical analogue of $\mathrm{Pu}(\mathrm{III})$ ) is affected by $\mathrm{NaCl}$ concentration [3]. Therefore, $\mathrm{Pu}$ sorption and $\mathrm{Pu}(\mathrm{IV}) / \mathrm{Pu}(\mathrm{III})$ redox equilibria at the illite surface are expected to be affected by the ionic strength.

\section{Materials and methods}

Chemicals (all pro analytical quality or better) were obtained from Merck (Darmstadt, Germany) or Riedel de Haen (Seelze, Germany). Solutions were prepared with de-ionized "MilliQ" water (specific resistivity, 18.2 $\mathrm{M} \Omega \mathrm{cm}^{-1}$ ). The purified Na-illite was provided within the EC project CP CatClay. The source material derives from lacustrine continental sediments deposited at the Upper Eocene ( $\sim-35 \mathrm{Ma})$ in the basin of Le Puy en Velay (Massif Central, France). The purification procedures and the characterization of the purified illite $(<63 \mu \mathrm{m})$ were previously detailed [21], and will not be repeated here. Note that in the last step of the purification, the clay suspension was freeze dried, to exclude bacterial activity. 


\subsection{Plutonium and Europium stock solutions}

A ${ }^{238} \mathrm{Pu}$ stock solution was prepared from $\mathrm{Pu}$ solution dissolved in nitric acid, which was fumed three times by $0.1 \mathrm{M} \mathrm{HClO}_{4}$, in order to remove all impurities and organic traces. The concentration of the Pu stock solution was $3.9 \times 10^{-5} \mathrm{M}$ in $0.1 \mathrm{M} \mathrm{HClO}_{4}$. From this, a more dilute solution $\left([\mathrm{Pu}]=1.9 \times 10^{-6} \mathrm{M}\right)$ in $0.1 \mathrm{M} \mathrm{HClO}_{4}$ was prepared for experiments at low $\mathrm{Pu}(\mathrm{IV})$ concentration. The diluted ${ }^{238} \mathrm{Pu}$ stock solution contained $85 \% \mathrm{Pu}(\mathrm{IV}), 11 \% \mathrm{Pu}(\mathrm{V})$ and $4 \%$ $\mathrm{Pu}(\mathrm{III})$, as determined by liquid-extraction methods [23]. Aqueous ${ }^{238} \mathrm{Pu}$ concentrations were determined by liquid scintillation counting (LSC) using the scintillation cocktail Ultima Gold XR with a liquid scintillation analyzer (Tri-Carb $3110 \mathrm{TR}$ ). In addition, the stock solution of ${ }^{238} \mathrm{Pu}$ was checked by ICP-MS and the results were in excellent agreement with LSC measurements. $\mathrm{Eu}(\mathrm{III})$ was used in some experiments as a chemical analogue of $\mathrm{Pu}(\mathrm{III})$. A radiotracer solution was purchased from Amersham International (total Eu concentration: $6.0 \times 10^{-4} \mathrm{M}$ ) with isotopic composition ${ }^{151} \mathrm{Eu}(83 \%),{ }^{152} \mathrm{Eu}\left(13 \%, \mathrm{t}_{1 / 2}=13.33 \mathrm{a}\right)$ and ${ }^{153} \mathrm{Eu}(4 \%) .{ }^{152} \mathrm{Eu}$ is a $\beta$-, $\gamma$-emitter and can be conveniently analyzed by $\gamma$-counting. In the present study, precise determination of dissolved ${ }^{152}$ Eu was performed using a Perkin Elmer Wallac gamma counter (Wizard 1480).

\subsection{Determination of $\mathrm{pH}$ and $\mathrm{Eh}$}

The $\mathrm{pH}$ in the clay suspensions was measured by an Orion 525A ( $\mathrm{pH}$ meter) and a Ross

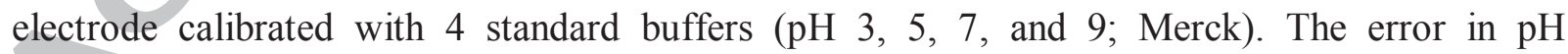
measurements is \pm 0.05 . For $\mathrm{pH}$ measurements in highly saline conditions ( $\mathrm{I}>0.1 \mathrm{~m}$ ) a correction term is applied to the measured operational $\mathrm{pH}$-values $\left(\mathrm{pH}_{\exp }\right)$. The molal proton concentration, i.e. $-\log m_{H^{+}}\left(\mathrm{pH}_{\mathrm{m}}\right)$, was obtained involving an empirical correction coefficient $\left(\mathrm{A}_{\mathrm{NaCl}}\right)$ according to equations 1 and 2: 
$p H_{m}=p H_{\text {exp }}+A_{\text {NaCl }}$

$A_{\mathrm{NaCl}}=0.0013 *\left(m_{\mathrm{NaCl}}\right)^{2}+0.1715 * m_{\mathrm{NaCl}}-0.0988$

$\mathrm{A}_{\mathrm{NaCl}}$ depends on background electrolyte composition and concentration and has been accurately determined for $\mathrm{NaCl}$ solutions for the electrodes we use [24]. $m_{\mathrm{NaCl}}$ is the molality $\left(\mathrm{mol} \mathrm{kg}^{-1}\right)$ of the background electrolyte.

The redox potentials in the clay suspensions were measured using an Orion $525 \mathrm{~A}\left(\mathrm{E}_{\mathrm{h}}\right.$ meter) and a Pt electrode combined with a $\mathrm{Ag} / \mathrm{AgCl}$ reference system (Metrohm). Raw data were converted into Eh vs. standard hydrogen electrode (SHE) by correcting for the potential of the reference electrode. Eh was converted to the apparent electron activity, pe $=-\log a_{e-}=$ $16.9 \times \mathrm{Eh}(\mathrm{V})$ at $25^{\circ} \mathrm{C}$. A commercial redox-buffer $(220 \mathrm{mV}$, Schott instruments $)$ was used for calibration. An equilibration time of 15 min was allowed for all Eh measurements, after having stirred the suspension. Uncertainties in Eh measurements are $\pm 50 \mathrm{mV}$ ( \pm 0.8 for pe-scale) [20, 25]. Unlike for the measurement of $\mathrm{pH}$, to our knowledge, there is no ionic strength dependent correction to apply to the experimental Eh with the presently used set-up.

\subsection{Batch sorption experiments}

All sorption studies were performed as batch type experiments. The procedure is the same as in our previous work dedicated to $m_{N a C l}=0.1 \mathrm{~m} \mathrm{[23].} \mathrm{The} \mathrm{effect} \mathrm{of} \mathrm{pH}_{\mathrm{m}}$ was investigated at an initial $\mathrm{Pu}$ concentration $\left([\mathrm{Pu}]_{\mathrm{tot}}\right)$ of $8 \times 10^{-11} \mathrm{M}$ in $3.2 \mathrm{~m} \mathrm{NaCl}$. In addition, the effect of $[\mathrm{Pu}]_{\mathrm{tot}}$ was investigated for $m_{\mathrm{NaCl}}=1.0$ and $3.2 \mathrm{~m}, 8 \times 10^{-11}<[\mathrm{Pu}]_{\mathrm{tot}}<10^{-8} \mathrm{M}$ and $\mathrm{pH}_{\mathrm{m}} \approx 4.5,6$ and 9.5. 
Batch experiments were carried out in $40 \mathrm{~mL}$ polypropylene centrifuge tubes at room temperature in an argon glove box $\left(<1 \mathrm{ppm} \mathrm{O}_{2}\right.$, absence of $\left.\mathrm{CO}_{2}\right)$. The suspension volume was $25 \mathrm{~mL}$. At a solid to liquid ratio of $2 \mathrm{~g} \mathrm{~L}^{-1}$, the suspensions were preconditioned in 1 or $3.2 \mathrm{~m} \mathrm{NaCl}$ under continuous shaking for 4-5 days to achieve a given target $\mathrm{pH}_{\mathrm{m}}$ value by adding $0.1 \mathrm{M} \mathrm{HCl}$ or 0.1 $\mathrm{M} \mathrm{NaOH}$. After adding $\mathrm{Pu}$ to the illite suspension, $\mathrm{pH}_{\mathrm{m}}$ was adjusted again to the respective target $\mathrm{pH}_{\mathrm{m}}$. Neither $\mathrm{pH}$ nor Eh buffers were used. The vials were then closed and shaken endover-end. According to previous studies [23, 26-29], potentially occuring redox processes might be rather slow. Consequently, an equilibration time of one year was chosen to make sure that equilibrium has established $[23,28]$. After one year, $\mathrm{pH}_{\mathrm{exp}}$ and $\mathrm{Eh}$ were measured in the suspension and an aliquot of each sample was transferred to centrifuge tubes (Beckmann, Recorder No.: 356562) and centrifuged (Beckmann Coulter XL-90 K) at 90,000 rpm ( 700,000 g max) for one hour. The supernatant was analyzed for dissolved Pu by LSC.

Results from the batch experiments will be expressed throughout as distribution coefficients $\left(\mathrm{R}_{\mathrm{d}}\right.$ in $\mathrm{L} \mathrm{kg}^{-1}$ ), calculated by the following equation:

$\mathrm{R}_{\mathrm{d}}=\left([\mathrm{Pu}]_{\mathrm{tot}} /[\mathrm{Pu}]_{\mathrm{aq}}-1\right) \times \mathrm{V} / \mathrm{m}$

where $[\mathrm{Pu}]_{\mathrm{aq}}$ and $[\mathrm{Pu}]_{\text {tot }}(\mathrm{M})$ are the dissolved (final) equilibrium and total (initial) concentrations of $\mathrm{Pu}$, respectively. The term $\mathrm{V} / \mathrm{m}$ corresponds to the aqueous solution volume to illite mass ratio $\left(\mathrm{L} \mathrm{kg}^{-1}\right.$ ). According to a previous experimental study [23], an uncertainty of \pm 0.2 is assigned to $\log \mathrm{R}_{\mathrm{d}}$, although it could be larger according to comparable studies where more than $99 \%$ uptake is obtained [6]. Under such conditions, larger uncertainties are induced by analytical constraints. 
Batch Eu sorption experiments were performed for $[\mathrm{Eu}]_{\mathrm{tot}}=3 \times 10^{-9} \mathrm{M}$ applying the same protocol as for $\mathrm{Pu}$, except that $\mathrm{Eh}$ was not recorded because $\mathrm{Eu}$ is not redox sensitive under our experimental conditions. After one week contact time and subsequent ultracentrifugation, the supernatant was analyzed for dissolved Eu by $\gamma$-spectrometry. The $m_{N a C l}$ values for $\mathrm{Eu}(\mathrm{III})(0.1$, 0.9 and $3.9 \mathrm{~m})$ slightly differ from those for $\mathrm{Pu}(0.1,1.0$ and $3.2 \mathrm{~m})$. This has no impact on our conclusions. Previous work suggested no significant effect of incorporation reactions or sorption by secondary phases on Eu/Pu uptake between 1 week and 1 year [23].

\subsection{Thermodynamic modeling}

pH-pe diagrams for $\mathrm{Pu}$ were constructed using PhreePlot [30], which contains an embedded version of the geochemical speciation program PHREEQC [31]. Thermodynamic constants for $\mathrm{Pu}$ and $\mathrm{Eu}$ aqueous speciation were taken from the NEA thermodynamic database [32]. Lanthanides and actinides exhibit similar chemical behavior for the same redox state and chemical analogues are often used to estimate the complex geochemical behavior of $\mathrm{Pu}[14,33]$. Therefore, in case of gaps in the $\mathrm{Pu}$ database, data for analogues were chosen (i.e. Eu(III), $\mathrm{Np}(\mathrm{IV}), \mathrm{Np}(\mathrm{V})$ and $\mathrm{U}(\mathrm{VI})$ for the respective Pu redox states). The specific ion interaction theory (SIT [12]) was used to calculate activity coefficients of aqueous species and the activity of water. These calculations are required in order to correct thermodynamic constants (including for redox equilibria) for ionic strength effects. SIT is generally considered valid for ionic strengths up to 3 $4 \mathrm{~m}$. Pitzer model [13], which is valid for a larger range of ionic strengths but more complex than SIT, can also be applied to calculate activity coefficients for aqueous ions in concentrated media (see e.g. [3]). SIT and Pitzer equations are implemented in PHREEQC but only SIT was used in 
this study. At $25{ }^{\circ} \mathrm{C}$, activity coefficients for an aqueous species $i\left(\gamma_{i}\right)$ with a charge $z_{i}$ are calculated as follows:

$\log \gamma_{i}=-z_{i}{ }^{2} \frac{0.509 \times \sqrt{I}}{1+1.5 \sqrt{I}}+\sum_{k} \varepsilon(i, k) \times m_{k}$

where $\mathrm{m}_{\mathrm{k}}$ is the molality of the aqueous species $k\left(\mathrm{~mol} \mathrm{~kg}^{-1}\right)$, and $\varepsilon(\mathrm{i}, \mathrm{k})$ is the specific ion interaction coefficient between species $i$ and $k\left(\mathrm{~kg} \mathrm{~mol}^{-1}\right)$. Auxiliary reactions and constants are from the SIT database provided with PHREEQC (sit.dat file). All parameters involved in Pu and Eu aqueous speciation calculations are listed in Tables S1 and S2 in the supporting information.

The 2 SPNE SC/CE model was used to simulate Pu and Eu sorption to illite. The cation exchange capacity (CEC) of the illite was set to $0.225 \mathrm{eq} \mathrm{kg}^{-1}$ [34]. Only the strong sites of the 2 SPNE SC/CE model are considered in the adsorption calculations with a site density of $2 \times 10^{-3}$ mol kg-1 [34]. The weak sites play a negligible role in our experiments, since a maximum loading of only $5 \times 10^{-6} \mathrm{~mol} \mathrm{~kg}^{-1}$ is investigated (i.e. for $[\mathrm{Pu}]_{\mathrm{tot}}=10^{-8} \mathrm{M}$ ). Surface complexation constants for $\mathrm{Eu}(\mathrm{III})$ and $\mathrm{Pu}(\mathrm{IV})$ extrapolated to zero ionic strength are available from previous work [23, 34]. These constants accurately predict $\mathrm{Eu}(\mathrm{III}), \mathrm{Pu}(\mathrm{III})$ and $\mathrm{Pu}(\mathrm{IV})$ uptake on the present illite in $0.1 \mathrm{~m} \mathrm{NaCl}$ [23]. A summary of the parameters for the 2SPNE SC/CE model is given in supporting information (Table S3).

\section{Results and discussion}

\subsection{Plutonium sorption to illite in solutions of different ionic strength}

Results of $\log \mathrm{R}_{\mathrm{d}}$ for the Pu-illite system $\left(8 \times 10^{-11}<[\mathrm{Pu}]_{\text {tot }}<10^{-8} \mathrm{M}\right)$ plotted versus $\mathrm{pH}_{\mathrm{m}}$ for $0.1,1$ and $3.2 \mathrm{~m} \mathrm{NaCl}$ are shown in Fig. 1a, $1 \mathrm{~b}$ and $1 \mathrm{c}$, respectively. Data for $0.1 \mathrm{~m} \mathrm{NaCl}$ are taken from our previous work [23]. Experimental $\mathrm{Pu}$ sorption data in $0.1<m_{\mathrm{NaCl}}<3.2 \mathrm{~m}$ are 
plotted together for comparison on Fig. 1d. Generally, $\mathrm{Pu}$ uptake on illite increases with $\mathrm{pH}_{\mathrm{m}}$ and remains constant for $\mathrm{pH}_{\mathrm{m}}>6$. For $\mathrm{pH}_{\mathrm{m}}<6$, Pu sorption decreases with increasing $m_{\mathrm{NaCl}}$, whereas it is not affected by $m_{\mathrm{NaCl}}$ for $\mathrm{pH}_{\mathrm{m}}>6$. Pu uptake data at $0.1 \mathrm{~m} \mathrm{NaCl}$ is explained by accounting for the presence of both $\mathrm{Pu}(\mathrm{III})$ and $\mathrm{Pu}(\mathrm{IV})$ for $\mathrm{pH}_{\mathrm{m}}<6$, where $\mathrm{Pu}$ (III) uptake is weaker than that of $\mathrm{Pu}(\mathrm{IV})$, whereas $\mathrm{Pu}(\mathrm{IV})$ prevails for $\mathrm{pH}_{\mathrm{m}}>6$ [23]. Experimental data for $\mathrm{Eu}(\mathrm{III})$ (taken as a chemical analogue for $\mathrm{Pu}(\mathrm{III})$ ) sorption to illite (for $m_{\mathrm{NaCl}}=0.1,0.9$ and 3.9 m) are included in Fig. 1. In agreement with a recent study on Eu(III) sorption to illite in saline solutions [3], $\log \mathrm{R}_{\mathrm{d}}(\mathrm{Eu}(\mathrm{III}))$ decreases with increasing $m_{N a C l}$ for $\mathrm{pH}_{\mathrm{m}}<6$, and is not affected by $m_{N a C l}$ for $\mathrm{pH}_{\mathrm{m}}>6$. The ionic strength dependence of $\log \mathrm{R}_{\mathrm{d}}(\mathrm{Pu})$ and $\log \mathrm{R}_{\mathrm{d}}(\mathrm{Eu})$ at $\mathrm{pH}_{\mathrm{m}}<6$ is consistent with the assumption of a cation exchange mechanism being at least partly responsible for the uptake of $\mathrm{Pu}(\mathrm{III})$. Note, however, that our $\mathrm{Pu}$ uptake data for $\mathrm{pH}_{\mathrm{m}}<6$ scatter significantly, which might be due to slight variations in redox conditions in individual batch experiments, as discussed later.

Fig. 2 shows all sorption data measured for $\mathrm{pH}_{\mathrm{m}}>6,8 \times 10^{-11}<[\mathrm{Pu}]_{\mathrm{tot}}<10^{-8} \mathrm{M}$ and $m_{\mathrm{NaCl}}$ $=0.1,1$ and $3.2 \mathrm{~m}$ as $\log \mathrm{R}_{\mathrm{d}}$ versus the logarithm of the final $\mathrm{Pu}$ concentration in solution after phase separation $\left(\log [\mathrm{Pu}]_{\mathrm{aq}}\right)$. Fig. 2 suggests that $\mathrm{Pu}$ uptake is not significantly influenced by $[\mathrm{Pu}]_{\text {tot }}$ or ionic strength within the range of concentrations investigated and for $\mathrm{pH}_{\mathrm{m}}>6 .[\mathrm{Pu}]_{\mathrm{aq}}$ in presence of illite is close to or below the solubility limit of $\mathrm{Pu}(\mathrm{IV})$ in equilibrium with $\mathrm{PuO}_{2 \text { (am,hydr) }}\left(10^{-10.4 \pm 0.5} \mathrm{M}[35]\right)$. But the more or less constant $\mathrm{R}_{\mathrm{d}}$ values even at the highest investigated $\mathrm{Pu}$ concentrations suggest the absence of significant precipitation or surface precipitation of $\mathrm{PuO}_{2(\mathrm{am}, \mathrm{hydr})}$. On average for all $m_{N a C l}$ investigated, $\log \mathrm{R}_{\mathrm{d}}=5.3 \pm 0.3(1 \sigma)$ for $\mathrm{pH}_{\mathrm{m}}>6$, which is in excellent agreement with previous work in $m_{\mathrm{NaCl}}=0.1 \mathrm{~m}\left(\log \mathrm{R}_{\mathrm{d}}=5.2 \pm\right.$ $0.2)[23]$. 
Fig. 3 shows pe values of all our experiments plotted versus $\mathrm{pH}_{\mathrm{m}}$ together with the predominance diagram for $\mathrm{Pu}$ in solution for $m_{\mathrm{NaCl}}=0.1 \mathrm{~m}$. The corresponding predominance fields in 1 and $3.2 \mathrm{~m} \mathrm{NaCl}$ shift because the activity coefficients of aqueous species vary with the ionic strength. Note that formation of aqueous $\mathrm{Eu}(\mathrm{III})-$ and $\mathrm{Pu}(\mathrm{IV})-\mathrm{Cl}$ complexes is almost insignificant $(<5 \%)$ for $0.1<m_{\mathrm{NaCl}}<3.2 \mathrm{~m}$ (preliminary calculations not shown). However, the ionic strength dependence of the $\mathrm{Pu}(\mathrm{III}) / \mathrm{Pu}(\mathrm{IV})$ redox borderline is minor relative to the uncertainty of measured pe (see Fig. S1). In view of the scattered experimental pe data we are not able to clearly identify an ionic strength dependence of $\mathrm{pH}_{\mathrm{m}}$-pe values, and the present results are in excellent agreement with previous studies in $m_{\mathrm{NaCl}}=0.1 \mathrm{~m}[21,23]$. The calculated predominance diagram and measured $\mathrm{pH}_{\mathrm{m}}$-pe values suggest that $\mathrm{Pu}(\mathrm{III})$ could predominate or exist in significant fractions at $\mathrm{pH}_{\mathrm{m}}<6$ and $\mathrm{Pu}(\mathrm{IV})$ becomes dominant above this $\mathrm{pH}_{\mathrm{m}}$. The pronounced ionic strength dependence of $\mathrm{Pu}$ uptake (comparable to that of $\mathrm{Eu}$ ) at low $\mathrm{pH}$ can thus easily be explained by the ion exchange competition of $\mathrm{Pu}^{3+}$ and $\mathrm{Na}^{+}[3,23,34]$. Based on our $\mathrm{pH} / \mathrm{pe}$ data, we can also conclude that the ionic strength independent experimental $\mathrm{Pu}$-illite sorption data at $\mathrm{pH}_{\mathrm{m}}>6$ are due to the exclusive presence of $\mathrm{Pu}(\mathrm{IV})$ undergoing innersphere surface complexation only $[6,31]$.

\subsection{Modeling results}

$\mathrm{Pu}(\mathrm{IV})$ uptake on illite is simulated for $m_{\mathrm{NaCl}}=0.1,1.0$ and $3.2 \mathrm{~m}$ with the $2 \mathrm{SPNE}$ SC/CE model. The same exercise is made for $\mathrm{Eu}(\mathrm{III})$ and $m_{\mathrm{NaCl}}=0.1,0.9$ and $3.9 \mathrm{~m}$. Previously reported surface complexation constants for $\mathrm{Pu}(\mathrm{IV})$ and $\mathrm{Eu}(\mathrm{III})$ are used for this purpose, without any parameter adjustment $[23,34]$. Results are shown in Fig. 1. In agreement with a previous study [3], the 2SPNE SC/CE model accurately predicts the effect of high $m_{N a C l}$ on Eu(III) uptake 
on the whole investigated $\mathrm{pH}_{\mathrm{m}}$ range, when appropriate ionic strength corrections for the activity coefficients of aqueous species are applied with SIT. For $\mathrm{pH}_{\mathrm{m}}<6, \mathrm{Eu}(\mathrm{III})$ sorption to illite decreases due to its competition with $\mathrm{Na}^{+}$for ion exchange sites whereas, for $\mathrm{pH}_{\mathrm{m}}>6, \mathrm{Eu}$ (III) uptake is weakly affected by the ionic strength because of the formation of innersphere Eu-illite surface complex [3]. Pu(IV) uptake on illite is predicted to be only weakly affected by the ionic strength in the range $0.1<m_{\mathrm{NaCl}}<3.2 \mathrm{~m}$. Model calculations agree with the observed absence of significant ionic strength effects on experimental uptake data of Th(IV) (taken as actinide analogue of $\mathrm{Pu}(\mathrm{IV}))$ on montmorillonite between 0.1 and $1.0 \mathrm{M} \mathrm{NaClO}_{4}$ [4], and the sorption data for $\mathrm{Pu}$ obtained in the present study for $\mathrm{pH}_{\mathrm{m}}>6$. These results support the assumption that tetravalent actinides undergo innersphere complexation rather than ion exchange at illite surface.

As previously inferred for actinide uptake on clays, the redox speciation of actinides is influenced by the formation of surface complexes [21-23]. The $\mathrm{Pu}(\mathrm{IV}) / \mathrm{Pu}(\mathrm{III})$ borderline at the illite surface (denoted as $\{\mathrm{Pu}(\mathrm{IV}) / \mathrm{Pu}(\mathrm{III})\}_{\text {surf }}$ ) is expected to depend on the individual $\mathrm{Pu}(\mathrm{IV})$ and $\mathrm{Pu}$ (III) sorption behavior [22-23], and can be calculated for $m_{\mathrm{NaCl}}=0.1,1.0$ and $3.2 \mathrm{~m}$ (Fig. 3) according to the following equation:

$$
\{P u(I V) / P u(I I I)\}_{\text {surf }}=\{P u(I V) / P u(I I I)\}_{a q}+\left(\log R_{d}(P u(I I I))-\log R_{d}(P u(I V))\right)
$$

$\{\mathrm{Pu}(\mathrm{IV}) / \mathrm{Pu}(\mathrm{III})\}_{\text {aq }}$ is the $\mathrm{Pu}(\mathrm{IV}) / \mathrm{Pu}(\mathrm{III})$ borderline in solution (i.e. plotted as a black line in Fig. 3), which is calculated using the Nernst equation. Values of $\log \mathrm{R}_{d}(\mathrm{Pu}(\mathrm{III}))$ and $\log \mathrm{R}_{\mathrm{d}}(\mathrm{Pu}(\mathrm{IV}))$ in eq. 5 represent the respective individual predicted uptake of the two $\mathrm{Pu}$ oxidation states under the same physico-chemical conditions (same $\mathrm{pH}$, ionic strength, etc), which can be seen in Figure 1a,b,c ("Pu(IV) only" and "Pu(III) only"). For all investigated $m_{N a C l}$ and $\mathrm{pH}_{\mathrm{m}}>6 \log \mathrm{R}_{\mathrm{d}}(\mathrm{Pu}(\mathrm{III}))$ 
$\approx \log \mathrm{R}_{\mathrm{d}}(\mathrm{Pu}(\mathrm{IV}))$ and, as a consequence, $\{\mathrm{Pu}(\mathrm{IV}) / \mathrm{Pu}(\mathrm{III})\}_{\text {aq }}$ and $\{\mathrm{Pu}(\mathrm{IV}) / \mathrm{Pu}(\mathrm{III})\}_{\text {surf }}$ coincide (Fig. 3). For $\mathrm{pH}<6,\{\mathrm{Pu}(\mathrm{IV}) / \mathrm{Pu}(\mathrm{III})\}_{\text {aq }}>\{\mathrm{Pu}(\mathrm{IV}) / \mathrm{Pu}(\mathrm{III})\}_{\text {surf }}$ because of the stronger sorption of $\mathrm{Pu}(\mathrm{IV})$ as compared to that of $\mathrm{Pu}(\mathrm{III})$. With increasing $m_{N a C l}$, log $\mathrm{R}_{\mathrm{d}}(\mathrm{Pu}(\mathrm{IV}))$ remains constant whereas $\log \mathrm{R}_{\mathrm{d}}(\mathrm{Pu}(\mathrm{III}))$ decreases. Hence, $\{\mathrm{Pu}(\mathrm{IV}) / \mathrm{Pu}(\mathrm{III})\}_{\text {surf }}$ decreases with increasing $m_{N a C l}$ (i.e. the $\mathrm{Pu}(\mathrm{IV}) / \mathrm{Pu}(\mathrm{III})$ borderline at the illite surface is shifted to lower pe). According to this model, when the redox conditions $(\mathrm{pH} / \mathrm{pe})$ fall between $\{\mathrm{Pu}(\mathrm{IV}) / \mathrm{Pu}(\mathrm{HI})\}_{\text {aq }}$ and $\{\mathrm{Pu}(\mathrm{IV}) / \mathrm{Pu}(\mathrm{III})\}_{\text {surf }} \mathrm{Pu}(\mathrm{III})$ prevails in solution whereas $\mathrm{Pu}(\mathrm{IV})$ prevails at the illite surface, and the overall $\mathrm{Pu}$ uptake by illite is intermediate to the individual uptake of $\mathrm{Pu}$ in the two distinct oxidation states [22,23].

When different $\mathrm{Pu}$ redox states coexist, the overall uptake of actinides on clays highly depends on pe [21-23]. As pointed out before, $\mathrm{R}_{\mathrm{d}}$ data scatter at acidic $\mathrm{pH}_{\mathrm{m}}$, which might be due to slight variations in redox conditions in individual batch experiments. The latter finding can be explained by the fact that the concentration of redox active components in the system is obviously low as discussed in a previous study on the interaction of $\mathrm{Np}$ with the same illite [21]. The exact nature of the redox partners determining measured pe values is not quite clear, but is most likely related to structurally bound $\mathrm{Fe}(\mathrm{II}) / \mathrm{Fe}(\mathrm{III})$. By using measured $\mathrm{pH}_{\mathrm{m}}$ and pe values as model input parameters, overall $\mathrm{Pu}$ uptake onto illite is calculated using the 2 SPNE SC/CE model and SIT without further parameter adjustment. Model results are plotted as empty symbols on Fig. 1a,b,c. In addition, Fig. 4 shows predicted versus experimental $\log \mathrm{R}_{\mathrm{d}}$ values. Both figures show good agreement of predicted and experimental Pu uptake onto illite. The average deviation between predicted and experimental results equals $0.3 \log R_{d}$ units (shown as bold dashed lines), which corresponds to the experimental uncertainty. Larger deviation (maximum 1 $\log \mathrm{R}_{\mathrm{d}}$ units, shown as thin dashed lines) can be observed for some data, especially for lowest log $R_{d}$ values, which might be attributed to uncertainties in pe measurements $( \pm 0.8)$. Indeed, these 
data were obtained in redox conditions $(\mathrm{pH} / \mathrm{pe})$ between $\{\mathrm{Pu}(\mathrm{IV}) / \mathrm{Pu}(\mathrm{III})\}_{\text {aq }}$ and $\{\mathrm{Pu}(\mathrm{IV}) / \mathrm{Pu}(\mathrm{III})\}_{\text {surf }}\left(3<\mathrm{pH}_{\mathrm{m}}<6\right.$; Fig. 3), for which predicted log $\mathrm{R}_{\mathrm{d}}$ values highly depend on pe [21-23]. Therefore, it is possible to conclude that the present model can accurately predict $\mathrm{Pu}$ sorption to illite under a large range of $\mathrm{pH}_{\mathrm{m}}$, pe and ionic strength conditions.

\section{Conclusions}

In this study, we provided experimental data for Pu sorption to illite under slightly reducing conditions $(2<$ pe $<10)$, where $\mathrm{Pu}(\mathrm{IV}) / \mathrm{Pu}$ (III) couple is involved, under saline conditions (up to $3.2 \mathrm{~m} \mathrm{NaCl}$ ), which are relevant for several potential deep geological nuclear waste repository sites. We observed that $\mathrm{Pu}$ sorption to illite was ionic strength dependent for $\mathrm{pH}_{\mathrm{m}}<6$ because of the presence of $\mathrm{Pu}(\mathrm{III})$ and its competition with $\mathrm{Na}^{+}$for ion exchange sites. By contrast, $\mathrm{Pu}$ sorption to illite did not depend on the ionic strength for $\mathrm{pH}_{\mathrm{m}}>6$, due to the predominance of $\mathrm{Pu}(\mathrm{IV})$, which undergoes innersphere surface complexation. According to our calculations, although $\mathrm{Pu}$ redox speciation in solution is only slightly influenced by $\mathrm{NaCl}$ concentration, $\mathrm{Pu}(\mathrm{IV}) / \mathrm{Pu}(\mathrm{III})$ redox equilibria at the illite surface can significantly be affected by the ionic strength when $\mathrm{pH}_{\mathrm{m}}<6$. Overall $\mathrm{Pu}$ uptake could be accurately predicted by the 2 SPNE SC/CE model coupled to SIT. Results of the present work together with the outcome of previous investigations [3,21-23] demonstrate that the proposed modeling approach is robust and applicable, at least for the investigated systems, and might be a reliable predictive tool for performance safety assessment for clays under highly saline conditions. This recently developed approach now covers effects of $\mathrm{pH}$, redox reactions and high background electrolyte concentrations, and allows estimating actinide sorption to clays at various redox conditions. Even 
at relatively low concentrations of redox governing components, measured pe still appears to be a meaningful parameter, which can be used to estimate retention of redox sensitive actinide ions and their redox speciation in solution and at the mineral surface with a quasi-mechanistic sorption model.

Nevertheless, the applicability of the approach to natural systems characterized by a high degree of heterogeneity and complexity still has to be demonstrated. Further studies dedicated to the uptake of actinides on natural soil- or clay rock formation-in situ porewater systems are therefore required to validate the present modeling approach. Our approach might also be tested for redox sensitive elements other than actinides (e.g. cerium, selenium, arsenic, chromium, iron) and adsorbing phases other than clays (e.g. oxides, natural organic matter).

Finally, non-electrostatic models were recently shown to be particularly suitable for the prediction of metal ion sorption to various types of surfaces in brines [3, 9-11], which is further demonstrated in this study, and would find applications not only in the field of nuclear waste disposal but also, for instance, in marine chemistry.

\section{Acknowledgements}

This work was financed by the Federal Ministry of Economic Affairs and Energy (Germany) under contracts No. 02E10206 and 02E10961. The research leading to these results has received funding from the European Union's European Atomic Energy Community's (Euratom) Seventh Framework Program FP7/2007-2011 under grant agreement nº 249624 (CATCLAY project).

\section{References}

[1] P. Vilks, Atomic Energy of Canada Limited, Toronto, Ontario, Canada, NWMO TR-2011-12, 2011. 
[2] S. Nagasaki, T. Saito, T. T. Yang J., Radioanal. Nucl. Chem., 308 (2016) 143.

[3] A. Schnurr, R. Marsac, T. Kupcik, T. Rabung, J. Lützenkirchen, H. Geckeis, Geochim. Cosmochim. Acta, 151 (2015) 192.

[4] M. H. Bradbury, B. Baeyens, Geochim. Cosmochim. Acta, 69 (2005) 875.

[5] M. H. Bradbury, B. Baeyens, Geochim. Cosmochim. Acta, 73 (2009) 990.

[6] M. H. Bradbury, B. Baeyens, Geochim. Cosmochim. Acta, 73 (2009) 1004.

[7] W. Brewitz, Zusammenfassender Zwischenbericht, GSF T 114, 1980.

[8] P. Fritz, S. K. Frape, Chem. Geol., 36 (1982) 179.

[9] J. Schijf, A. M. Ebling, Environ. Sci. Technol., 44 (2010) 1644.

[10] A. Zoll, J. A M. Schjif, Geochim. Cosmochim. Acta, 97 (2012) 183.

[11] D. A. Ams, J. S. Swanson, J. E. S. Szymanowski, J. B. Fein, M. Richmann, D. T. Reed, Geochim. Cosmochim. Acta, 110 (2013) 45.

[12] L. Ciavatta, Annali Di Chimica, 70 (11-1) (1980) 551.

[13] K. S. Pitzer, CRC Press, Boca Raton, 1991.

[14] M. Altmaier, X. Gaona, T. Fanghanel, Chem. Rev., 113 (2013) 901.

[15] H. Geckeis, J. Lutzenkirchen, R. Polly, T. Rabung, M. Schmidt, Chem. Rev., 113 (2013) 1016.

[16] C. M. Marquardt, A. Seibert, R. Artinger, M. A. Denecke, B. Kuczewski, D. Schild, T. Fanghanel, Radiochim. Acta, 92 (2004) 617.

[17] D. I. Kaplan, B. A. Powell, M. C. Duff, D. I. Demirkanli, M. Denham, R. A. Fjeld, F. J. Molz, Environ. Sci. Technol., 41 (2007) 7417.

[18] R. A. Buda, N. L. Banik, J. V. Kratz, N. Trautmann, Radiochim. Acta, 96 (2008) 657.

[19] G. Lujanienè, J. Šapolaité, E. Radžiutè, V. Aninkevičius, J. Radioanal. Nucl. Chem., 282 (2009) 793.

[20] R. Kirsch, D. Fellhauer, M. Altmaier, V. Neck, A. Rossberg, T. Fanghanel, L. Charlet, A. C. Scheinost, Environ. Sci. Technol., 45 (2011) 7267.

[21] R. Marsac, N. L. Banik, J. Lutzenkirchen, C. M. Marquardt, K. Dardenne, D. Schild, J. Rothe, A. Diascorn, T. Kupcik, T. Schafer, H. Geckeis, Geochim. Cosmochim. Acta, 152 (2015) 39.

[22] R. Marsac, N. L. Banik, J. Lützenkirchen, R. A. Buda, J. V. Kratz, C. M. Marquardt, Chem. Geol., 400 (2015) 1.

[23] N. L. Banik, R. Marsac, J. Lützenkirchen, A. Diascorn, K. Bender, C. M. Marquardt, H. Geckeis, Environ. Sci. Technol., 50 (2016) 2092.

[24] M. Altmaier, V. Metz, V. Neck, R. Müller, Th. Fanghänel, Geochim. Cosmochim. Acta, 67 (2003) 3595.

[25] M. Altmaier, X. Gaona, D. Fellhauer, G. Buckau, Intercomparison of redox determination methods on designed and near-neutral aqueous systems, Karlsruhe, 2010. 
[26] B. A. Powell, R. A. Fjeld, D. I. Kaplan, J. T. Coates, S. M. Serkiz, Environ. Sci. Technol., 39 (7) (2005) 2107.

[27] M. Zavarin, B. A. Powell, M. Bourbin, P. H. Zhao, A. B. Kersting, Environ. Sci. Technol., 46 (5) (2012) 2692.

[28] J. D. Begg, M. Zavarin, P. H. Zhao, S. J. Tumey, B. Powell, A. B. Kersting, Environ. Sci. Technol., 47 (2013) 5146.

[29] A. E. Hixon, B. A. Powell, Environ. Sci. Technol., 48 (2014) 9255.

[30] D. G. Kinniburgh, D. M. Cooper, PhreePlot: Creating graphical output with PHREEQC.

http://www.phreeplot.org. 2009.

[31] D. L. Parkhurst, C. A. J. Appelo, User's guide to PHREEQC (Version 2) - a computer program for speciation, batch reaction, one-dimensional transport and inverse geochemical calculation; Denver, Colorado, (1999) 312.

[32] R. Guillaumont, Th. Fanghänel, J. Fuger, I. Grenthe, V. Neck, D. A. Palmer, M. H. Rand, Update on the Chemical Thermodynamics of Uranium, Neptunium, Plutonium, Americium and Technetium; Elsevier: Amsterdam, 2003.

[33] G. R. Choppin, Radiochim. Acta 85 (1999) 89-95.

[34] M. H. Bradbury, B. Baeyens, H. Geckeis, T. Rabung, Geochim. Cosmochim. Acta, 69 (2005) 5403.

[35] V. Neck, M. Altmaier, T. Fanghanel, C. R. Chim., 10 (2007) 959. 


\section{Figure Caption}

Fig. 1. $\mathrm{Pu}$ sorption to illite $\left(\log \mathrm{R}_{\mathrm{d}}\right.$ in $\mathrm{L} \mathrm{kg}^{-1}$ ) versus $\mathrm{pH}_{\mathrm{m}}\left(=-\log m_{H^{+}}\right.$) in (a) 0.1 (taken from our previous work [23]), (b) 1.0 and (c) $3.2 \mathrm{~m} \mathrm{NaCl}$. (d) Experimental Pu sorption data in $0.1<$ $m_{\mathrm{NaCl}}<3.2 \mathrm{~m}$ are plotted together for comparison. Experimental Eu(III)-illite sorption data for similar $m_{\mathrm{NaCl}}$ ((a) 0.1, (b) 0.9 and (c) $3.9 \mathrm{~m} \mathrm{NaCl}$ ) are shown for comparison. Solid and dashed lines show the predicted uptake of $\mathrm{Pu}(\mathrm{IV})$ (taken as independent component) and $\mathrm{Eu} / \mathrm{Pu}(\mathrm{III})$, respectively. Empty symbols are model overall $\mathrm{Pu}$ sorption results using measured $\mathrm{pH} / \mathrm{pe}$ values as input parameters.

Fig. 2. Experimental data for $\mathrm{Pu}$ sorption onto illite $\left(\log \mathrm{R}_{\mathrm{d}}\right.$, in $\left.\mathrm{L} \mathrm{kg}^{-1}\right)$ versus the final $\mathrm{Pu}$ concentration in solution after phase separation $\left(\log [\mathrm{Pu}]_{\mathrm{aq}}\right.$, in $\left.\mathrm{M}\right)$ for $\mathrm{pH}_{\mathrm{m}}>6$ and $0.1<m_{\mathrm{NaCl}}<$ $3.2 \mathrm{~m}$ (data for $0.1 \mathrm{~m} \mathrm{NaCl}$ are taken from our previous work [23]). The average log $\mathrm{R}_{\mathrm{d}}(=5.3)$ is shown as a line, associated with an uncertainty of \pm 0.3 ( $1 \sigma$; dashed lines).

Fig. 3. The pe values measured in the illite suspensions in $m_{N a C l}=0.1,1$ and $3.2 \mathrm{~m}$ are plotted versus $\mathrm{pH}_{\mathrm{m}}\left(=-\log m_{H^{+}}\right)$. Data for $0.1 \mathrm{~m} \mathrm{NaCl}$ are taken from our previous work [23]. The black lines correspond to the predominance $\mathrm{pH}_{\mathrm{m}}$-pe diagram for $\mathrm{Pu}$ in solution calculated for $m_{\mathrm{NaCl}}=$ $0.1 \mathrm{~m}$ and $[\mathrm{Pu}]_{\text {tot }}=10^{-11} \mathrm{M}$. The thick colored lines correspond to the $\mathrm{Pu}(\mathrm{IV}) / \mathrm{Pu}(\mathrm{III})$ borderline at the illite surface for $m_{\mathrm{NaCl}}=0.1 \mathrm{~m}$ (blue), $1.0 \mathrm{~m}$ (green) and $3.2 \mathrm{~m}$ (red).

Fig. 4. Modeled versus experimental $\log \mathrm{R}_{\mathrm{d}}$ values for the whole dataset (present data for $m_{\mathrm{NaCl}}$ $=1.0$ and $3.2 \mathrm{~m}$ and from our previous work for $m_{\mathrm{NaCl}}=0.1 \mathrm{~m} \mathrm{[23]).} \mathrm{The} \mathrm{1:1} \mathrm{(solid)} \mathrm{line,}$ associated with an uncertainty of $\pm 0.3 \log \mathrm{R}_{\mathrm{d}}$ units (bold dashed lines), which corresponds to both the experimental uncertainty on $\log \mathrm{R}_{\mathrm{d}}$ and the average deviation between experimental and modeled results, and an uncertainty of $\pm 1 \log R_{d}$ units (thin dashed lines), which corresponds to the largest deviation between experimental and modeled results. 
Fig. 1
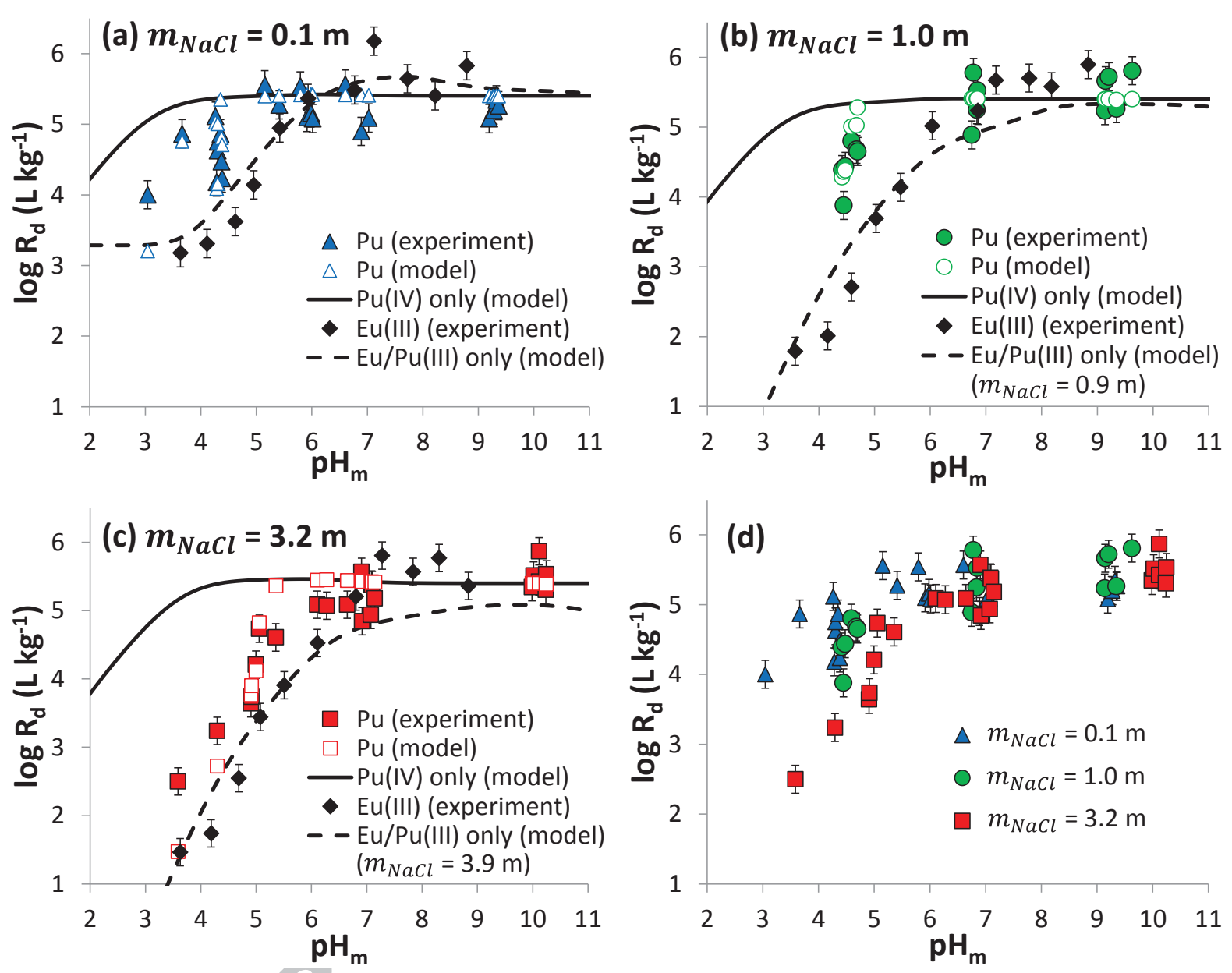
Fig. 2

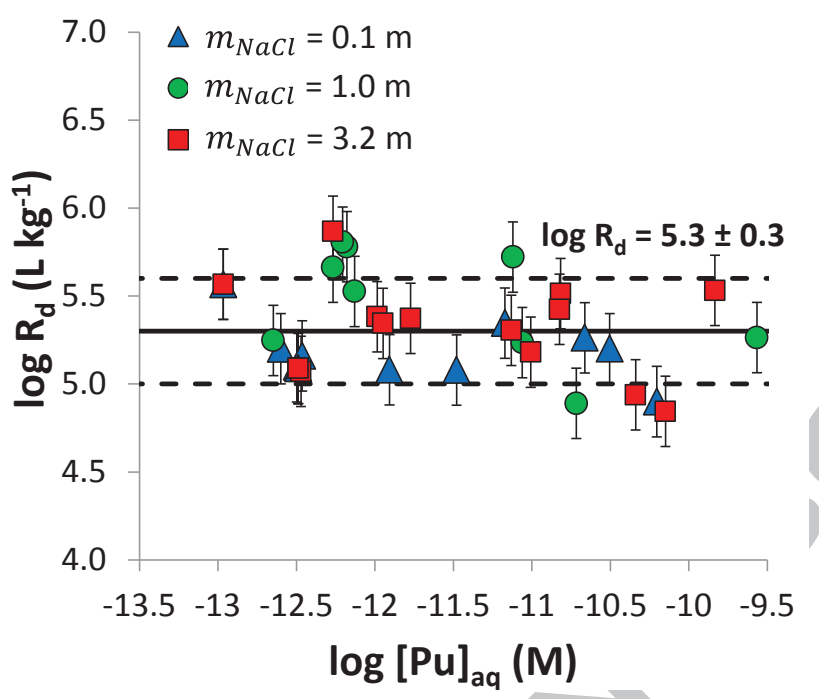


Fig. 3

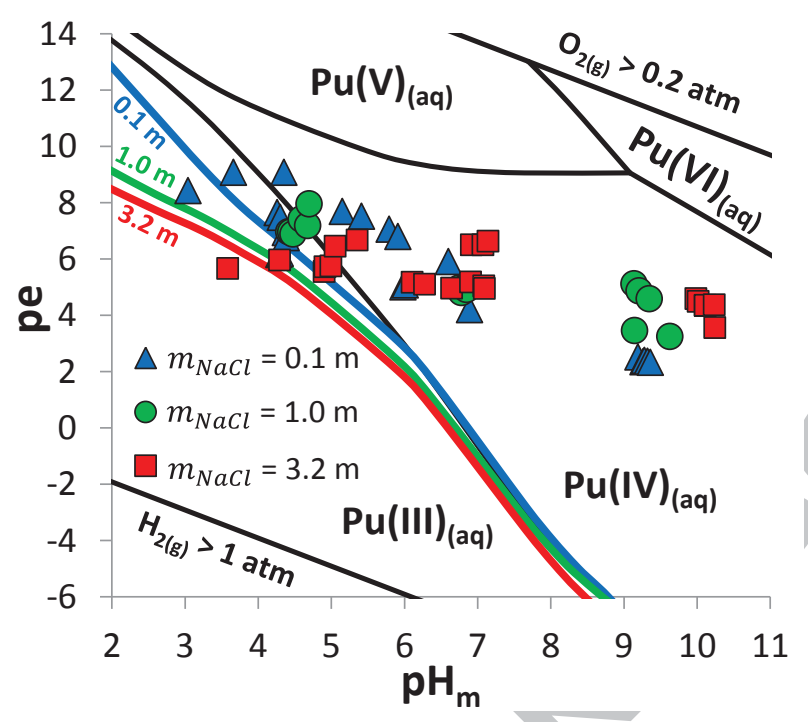


Fig. 4

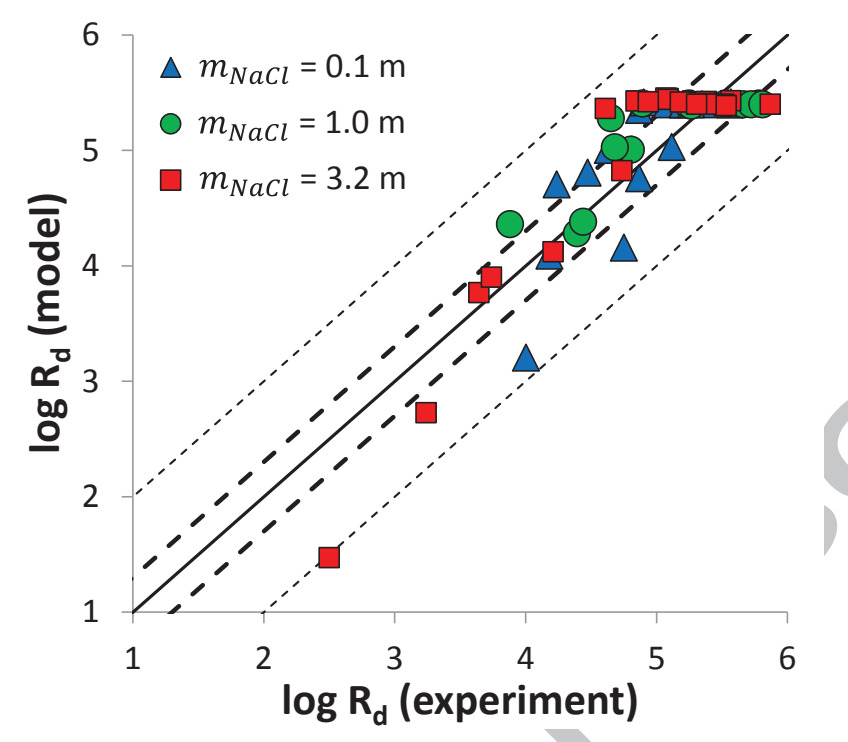

